\title{
An updated review on Couroupita guianensis Aubl: a sacred plant of India with myriad medicinal properties
}

\author{
Lawrence Anna Sheba ${ }^{1,2} \mathbb{D}$, Venkatraman Anuradha ${ }^{1^{*} \mathbb{D}}$ \\ ${ }^{1} \mathrm{PG}$ and Research Department of Biochemistry, Mohamed Sathak College of Arts and Science, Chennai, Tamilnadu, India \\ ${ }^{2}$ Department of Biochemistry, Soka Ikeda College of Arts and Science, Chennai-53, India
}

\section{A R T I C L E I N F O}

Article Type:

Review

\section{Article History:}

Received: 3 June 2019

Accepted: 23 June 2019

\section{Keywords:}

Cannonball tree

Wound healing

Anticancer

Isatin

Tryptanthrin

Indirubin

\begin{abstract}
A B S T R A C T
From ancient times, medicinal plants have been making important contributions to mankind owing to their healing properties. Their fundamental aspects such as safety, quality, and efficiency ensure the role of plant-based medicines in healthcare. Couroupita guianensis Aubl, commonly known as cannonball tree, is a member of the family Lecythidaceae (Brazil-nut family). Cannonball tree has gained worldwide attention because of its immense therapeutic values including antibiotic, antiseptic, anti-inflammatory, antimicrobial, antimycobacterial, analgesic, antiarthritic, anti-biofilm, antidiarrheal, antifertility, antipyretic, antistress, antitumor, antiulcer, antidermatophytic, wound healing and immunomodulatory activities. Almost all parts of the tree have been used traditionally for treating various ailments. It has been reported that C. guianensis is a rich source of bioactive compounds, specifically the presence of isatin, tryptanthrin, and indirubin is noteworthy. The present review covers in-depth literature survey concerning ecology, morphology, ethnopharmacology, phytochemistry and toxicological information of C. guianensis. This review attempts to summarise information relating to the medicinal value of C. guianensis to date in order to provide baseline knowledge for future works.
\end{abstract}

Implication for health policy/practice/research/medical education:

This review provides up to date information on phytochemistry and multiple biological activities of Couroupita guianensis Aubl. establishing a wider interest in safety application to humans in future.

Please cite this paper as: Anna Sheba L, Anuradha V. An updated review on Couroupita guianensis Aubl: a sacred plant of India with myriad medicinal properties. J Herbmed Pharmacol. 2020;9(1):1-11. doi: 10.15171/jhp.2020.01.

\section{Introduction}

Ever since the beginning of life on earth, mankind has kept a close association with the botanical wealth to fulfil their basic needs such as shelter, clothing, food, and medicine. Ancient people value the plants as natural healers and have given a prominent position in their livelihood. Through many centuries, they have kept on observing and experimenting on medicinal plants and have accumulated a rich knowledge on their medicinal properties. This has led to the development of the indigenous system of medicine such as Ayurveda, Unani, Siddha, Chinese and others $(1,2)$.

Traditional medicine remains the mainstay for promoting and maintaining good health in developing countries. Although the dependency varies between developed and developing countries, the majority (80\%) of world's population depend on traditional medicine either as plant extracts or their active principles to meet their primary healthcare (2). Medicinal plants are reported to be rich in bioactive secondary metabolites, thereby act as a renowned supply of drugs being utilized in folklore to modern medicine for therapeutic purposes. Besides their therapeutic potencies, their holistic approach, self-contained nature, safety, and adequacy make them inevitable as a root for alternative medicine.

Couroupita guianensis Aubl (Figure 1) belonging to Lecythidaceae family is well known for its medicinal and ornamental values. It is commonly called a Cannonball tree because of the cannonball appearance of its fruits. It is a large deciduous tropical evergreen tree widely cultivated as an ornamental plant for its distinctive flower and fruit. It is more common among tribes and rural people (3) and widely used in traditional medicine. The trees were overexploited during the past for timber, settlement, and agriculture and so it is under the category of threatened medicinal plant and has been enrolled in 


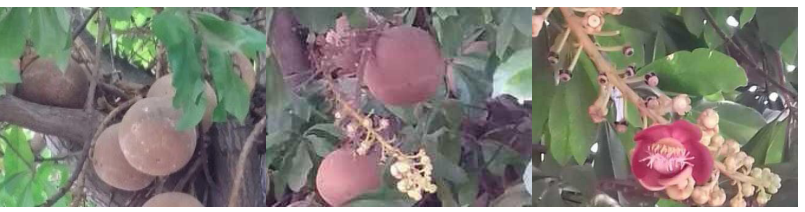

Figure 1. Cannonball tree.

International Union for Conservation of Nature (IUCN) red list. In India, it is regarded as a sacred tree. Its flower is proclaimed as the State flower by the government of Puducherry, Union territory of India (4). Till now there are solely a few reviews available on C. guianensis (CG). These reviews elaborated on the phytochemistry and pharmacological activities of C. guianensis. The present review encompasses a comprehensive literature survey in PubMed, Google Scholar, Science Direct, web of science and books covering articles, reviews and chapters related to C. guianensis till 2018 and summarises information on botanical classification, distribution, morphology, phytochemistry, biological activities and up to date information in the research findings related to $C$. guianensis.

\section{Origin, distribution and morphology}

Cannonball tree is native to the dense tropical rainforest of north-eastern South America, particularly in the Amazon Basin. It is also indigenous to Central America (Costa Rica, Panama), Western South America (Colombia, Ecuador, Peru) and Brazil (5). It is thought to be native to India, Sri Lanka and Malaysia as well. In India, it is grown throughout the plains. It is widely grown as an ornamental tree in Botanical gardens and a sacred tree in Shiva temples. The curved staminal sheath of the flower over the pistil resembles Linga, a sacred snake protecting Lord Shiva (6) and hence used in the worship of Lord Shiva. The tree is popular among the tribal population, such as Shamans of South America (7), Nigerian rural population (8), Kailasagirikona forest range rural people (9), Yanadi tribes in Seshachalam biosphere reserve forest of Chittoor district, Andhra Pradesh, India (10) and people of Gournadi Upazila, Barisal district and Bangladesh. It is planted in roadsides of different districts of Bangladesh (11).

Couroupita guianensis is a fast-growing gigantic tree reaching a height of up to $30-35 \mathrm{~m}$ tall. The leaves are simple, alternate, oblong or oblong-ovate up to $10 \mathrm{~cm}$ long with entire to slightly serrate margin and a short petiole and hairy on the veins beneath. They are arranged in whorls at the end of the shoot $(8,12)$. The tree bears racemose and cauliflorous inflorescence of about 3 $\mathrm{m}$ long. The flowers are large and flashy, show up in various colors like orange, scarlet or pink with a pleasant fragrance, almost throughout the year. They are strongly scented, especially at night and in the early morning (13).
Sepals are short and six in number whereas petals are broad and also numbered six. Petals are unequal, concave; pink inside but with a mixture of white, yellow and pink outside. Stamens are numerous, arranged on a band that arises from the base of the ovary and bend over it forming a curved fleshy androphore. Most of the stamens are fertile, but some abortive stamens are also seen at the base of the band surrounding the ovary. Ovary is 5-7 celled and the cells are many-ovuled $(4,12,14)$. The flowers mature into large, reddish-brown, spherical, woody, indehiscent and amphisarcun (double fleshy) fruits of about 15-24 $\mathrm{cm}$ diameter and encased in a hard shell. Each tree bears around 150 fruits and takes up 1 year or nearly 18 months to mature. Each fruit weighs about 36 pounds (15). The fruit contains numerous (200-300) seeds in a white, vinous and acidic pulp. The pulp fills the whole shell and differs in color indicated by the degree of maturity. The pulp oxidizes to bluish-green when exposed to air. It is rich in sulfur compounds which gives its disagreeable odor. Thus regardless of the palatability of fruits, they are occasionally consumed $(14,16,17)$. The plant is propagated by seeds. However, the seeds are reported to be recalcitrant with short life span (4).

\section{Scientific classification}

Kingdom: Plantae - Plants

Subkingdom: Tracheobionta

Superdivision: Spermatophyta

Division: Magnoliophyta

Class: Magnoliopsida

Subclass: Dilleniidae

Order: Lecythidales

Family: Lecythidaceae - Brazil-nut family

Genus: Couroupita Aubl

Species: Couroupita guianensis Aubl (18).

\section{Vernacular names of Couroupita guianensis}

As already mentioned, CG has been widespread across the world. This plant has different names in various countries. The vernacular names have been specified in Table 1 (in India) and Table 2 (other parts of the world) (19).

\section{Traditional uses}

Couroupita guianensis is popular among the tribal communities in the context of its medicinal values. Literature survey reveals that the cannonball tree is known for its cultural importance for many centuries. In India, the tree is considered as a sacred, widely seen in Lord Shiva temples. All of its parts have been utilized by natives to treat a wide spectrum of human illness such as hemorrhage, piles, scabies, dysentery, scorpion sting, hypertension, tumors, malaria, odontalgia, inflammatory processes, kidney and stomach problems, allergies, ulcers, toothache, and skin diseases. The rural people elsewhere in the world use various parts of the plant to 
Table 1. Vernacular names of Couroupita guianensis in India

\begin{tabular}{ll}
\hline Name & Language \& State \\
\hline Naglingom, Nag-champa B & Assamese/Assam \\
Kaman Gola & Bengali/ Bengal \\
Kailasapati, Shivalingi & Gujarati/ Gujarat \\
Tope Gola, Nagalinga & Hindi \\
Lingada Mara, Nagalingam & Kannada/ Karnataka \\
Kailasapati & Marathi/Maharashtra \\
Naaga danthee & Malayala/Kerala \\
Nagakesara, Nageshwara & Odia/Orissa \\
Naagalingam & Tamil/Tamil Nadu \\
Mallikarjuna, Naagamalli, Naagalingam & Telugu/Andhra Pradesh, \\
\end{tabular}

Table 2. Vernacular names of Couroupita guianensis throughout the world

\begin{tabular}{ll}
\hline Name & Language/Country \\
\hline Coco sachapura, Maraca & Colombia \\
Bala de canon & Costa Rica \\
Kanonskogelboom & Dutch \\
Cannonball tree & English \\
Arbre À Boulet De Canon & French \\
Kanonenkugelbaum & German \\
Sala & Indonesia \\
Coco Sachapura, Granadillo de Las Huacas & Panama \\
Bola De Canon, Coco De Mono & Spanish \\
Sala Lankaa & Thai \\
\hline
\end{tabular}

treat microbial infections. Additionally, it is also widely used as a veterinarian plant. In the indigenous Ayurveda medicine, C. guianensis is used as a rubefacient, antiinflammatory and antirheumatic medicine. The leaves, bark and flowers are frequently used as infusion or tea by the Native Amazonian people of Amazon region and other states of the north region of Brazil (20) to treat hypertension, tumor, pain and inflammation. Further, the infusion of flowers is used as immunobooster. Likewise, leaves, roots and bark are utilized by Shamans of South America for treating malaria (21). The leaves are used as snuff in the powdered form. In India, Kailasagirikona tribes and Yanadi tribes claim that leaves act as an effective hair vitalizer $(9,10)$. Fruits are edible but their unpleasant smell deters most people from endeavoring them. However, the fruits are consumed by the Negroes of Guiana and are used for the preparation of the medicinal drink (22). The overall traditional uses of CG are pointed out in Table 3.

\section{Phytochemistry}

Physical factors like temperature, humidity, rainfall and sunlight and other factors like soil nutrients influence the synthesis of bioactive compounds in plants. Studies dedicated to C. guianensis have reported the identification and isolation of various categories of phytochemicals from different parts of the tree. The terpenes, flavonoids, phytosterols, alkaloids and phenolic acids are considered the most dominant family of components occurring in the cannonball tree. The fruits of cannonball tree are apparently rich in alkaloid, tryptanthrin and indirubin. Earlier, Sen et al isolated couroupitine A from the petroleum ether extract and couroupitine B from the chloroform extract of the dried and powdered fruits (30). Later Bergman et al proved the structure of these compounds, couroupitine A and couroupitine $\mathrm{B}$ to be identical with tryptanthrin and indirubin respectively (31).

The chemical composition varies with the level of maturation. For instance, mature fruits contain more amount of anthocyanin compared to young fruit, whereas, phenolic contents are more in young fruits and flowers compared to mature fruits and flowers (35). The chemical constituents are summarised in Table 4.

\section{Pharmacological activities}

Cannonball tree has been widely screened for its various pharmacological activities. The reported pharmacological activities of the cannonball tree highlight the therapeutic

Table 3. Traditional uses of Couroupita guianensis

\begin{tabular}{ll}
\hline Parts of the plant & Traditional uses \\
\hline Flower & $\begin{array}{l}\text { Immunobooster and snuff. Cold, intestinal gas formation and stomach ache, diarrhea, hypertension, tumor, } \\
\text { pain, inflammation, antibacterial, antifungal and asthma }\end{array}$ \\
\hline Leaves & $\begin{array}{l}\text { Hair vitalizer, Skin disorders, toothache, antiseptic, antibacterial, antifungal, antithrombotic, vasodilatory, } \\
\text { dysentery, snake bite, arthritis, asthma, hypertension, tumor, pain, Inflammation, rheumatic disorders and } \\
\text { malaria. }\end{array}$ \\
\hline Bark & $\begin{array}{l}\text { Skin infection, antibacterial and antifungal, snake bite, hypertension, tumor, pain, inflammation, malaria and } \\
\text { snake bite. }\end{array}$ \\
\hline Seeds & Reproductive disorders and infertility. \\
\hline Fruit & $\begin{array}{l}\text { Cold, wound, headache, stomach ache, antibacterial, antifungal and medicinal drink. } \\
\text { Utensil }\end{array}$ \\
\hline Root & Malaria \\
\hline
\end{tabular}




\begin{tabular}{|c|c|c|}
\hline Part of the plant & Chemical constituents & References \\
\hline Fruit & $\begin{array}{l}\text { Couroupitine A (tryptanthrin), Couroupitine B (indirubin), malic acid, isocitric acid, stigmasterol, campesterol, } \\
\text { hopane, rutin, quercetin, kaempherol, farmaricetin, luteolin and ursolic acid }\end{array}$ & $(30-35)$ \\
\hline Flower & $\begin{array}{l}\text { Eugenol, linalool, (E, E)-farnesol, nerol, geraniol, (Z, E)-farnesol, vanillin, limonene and geranial, (E, E)- } \\
\text { farnesyl acetate, trans ocimene, nootkatone, geraniol, 2-isopropenyl-5-methyl-4-hexenyl acetate), cedr-8- } \\
\text { en-13-ol, (E,Z)-farnesyl acetate, methyl (11E)-11-hexadecenoate, isatin, cycloart-24-en3-ol-3'-exomethylene } \\
\text { heptadeconate, stigmasterol, p-coumaric acid, o-coumaric acid, caffeic acid, quercetin, octyl 4-(nonanoyloxy) } \\
\text { benzoate, myristoleic acid, linoleic acid, (8E, 10E, 12E)-icosa-8, 10, 12-triene) }\end{array}$ & $(23,36-39)$ \\
\hline Leaf & $\begin{array}{l}\text { Triterpenic ester } \beta \text {-amirin palmitate, hydroxycinnamic acids, caffeic acid, rosmarinic acid, kaempferol-3- } \\
\text { O-neohesperidoside, 20, 40-dihydroxy-60-methoxy-30,50-dimethylchalcone, 7-hydroxy-5-methoxy-6,8- } \\
\text { dimethylflavanone, 4-hydroxybenzoic acid }\end{array}$ & $(27,40)$ \\
\hline Seed & Indigo, indirubin, stigmasterol, campesterol, linoleic acid, nerol, tryptanthrin & (4) \\
\hline Stem and Bark & 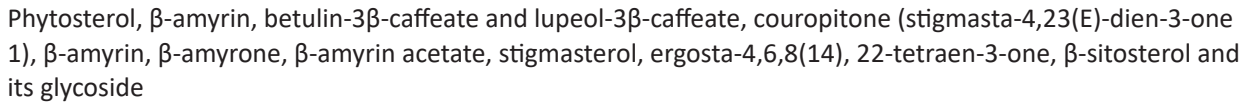 & $(11,41-42)$ \\
\hline
\end{tabular}

potential of the tree.

\section{Antioxidant activity}

Extracts obtained from different parts of CG have exhibited a significant antioxidant effect as demonstrated in several studies. Leaf, stem and flower extracts exhibited variable scavenging activities with respect to $\mathrm{DPPH}$, hydrogen peroxide, nitric oxide and hydroxyl radicals. Importantly, ethylacetate leaf extract has shown the highest scavenging activity against $\mathrm{DPPH}$, hydrogen peroxide and hydroxyl radicals with $\mathrm{IC}_{50}$ values of 17.25, $55.1 \pm 0.04$ and $240 \pm 0.81 \mu \mathrm{g} / \mathrm{mL}$, respectively. Similarly, ethylacetate stem extract inhibited nitric oxide radical with an $\mathrm{IC}_{50}$ value of $50.4 \pm 0.31 \mu \mathrm{g} / \mathrm{mL}$ (43). In another study carried out by Kekuda, marked scavenging activity against 2,2'-azino-bis-3-ethylbenzthiazoline-6-sulfonic acid was provided by the methanol extract of the leaf $\left(\mathrm{IC}_{50}\right.$ value $7.63 \mu \mathrm{g} / \mathrm{mL}$ ) (11). Likewise, the methanol extract of flowers and ethanol extract of the leaves have also been found to exhibit antioxidant activities (44). The variations in antioxidant activities might be due to the method of extraction and the solvent used. In a study amongst all the extracts studied, cold percolation aqueous extract of leaf showed high phenol content $(91.87 \pm 0.113 \mathrm{mg} / \mathrm{g})$ and thus maximum DPPH free radical scavenging activity and ferric reducing antioxidant power with a percentage inhibition of $85.43 \pm 0.155$ and $11.85 \pm 0.155$ respectively at a concentration of $100 \mu \mathrm{g} / \mathrm{mL}$ (45). Meanwhile, on assessing the effect of maturation on the in vitro antioxidant activities, it has been evident that young stages of leaf and fruit exhibited higher total phenols, flavonoids, ortho-dihydric phenols and anthocyanin and also maximum scavenging activity (35).

\section{Antimicrobial activity}

A study highlighted the antibacterial activity of aqueous, chloroform and ethyl acetate extracts of leaf, flower and fruit against Escherichia coli, Bacillus subtilis and Pseudomonas aeruginosa and found that the chloroform and ethyl acetate extracts were predominant in phytochemicals and thus exhibiting higher zone of inhibition (ZI) comparable to that of streptomycin used as a positive control. Amongst the various extracts, the chloroform leaf, flower and fruit extracts exhibited significant antibacterial activity against E. coli and B. subtilis, specifically the chloroform fruit extract showed maximum antibacterial activity against $P$. aeruginosa with an inhibition zone of $14 \mathrm{~mm}$ (46). In a similar study, chloroform fruit extract displayed moderate activity against gram-positive bacteria, B. subtilis (14 mm), Micrococcus luteus (18 mm), Enterobacter aerogenes (19 $\mathrm{mm}$ ) and Staphylococcus aureus $(26 \mathrm{~mm})$, gram-negative bacteria Shigella flexneri (20 mm), Klebsiella pneumonia $(18 \mathrm{~mm}), P$. aeruginosa $(8 \mathrm{~mm})$ and Proteus vulgaris (12 $\mathrm{mm})$. Further, the same extract showed $52 \%$ antibiofilm activity against $P$. aeruginosa at $2 \mathrm{mg} / \mathrm{mL} \mathrm{BIC}$, thereby demonstrating its ability to complex with the bacterial cell wall (47). In another study the ethanol fruit rind extract (at $10 \mathrm{mg} / \mathrm{mL}$ ) showed moderate activity against $S$. aureus, $E$. coli, C. diphtheriae and Micrococcus sp. (34). These studies proved that both fruit rind and fruit pulp were active in inhibiting the growth of microorganisms. Flowers of CG were effective against Salmonella enterica, E. coli, S. aureus and Proteus vulgaris and fish-borne pathogens such as Vibrio mimicus and Plesiomonas shigelloides $(24,48)$. Flowers were also reported to exhibit antibacterial activity against multidrug-resistant strains viz methicillinsensitive Staphylococcus aureus ATCC 29213, methicillinresistant $S$. aureus (wild type) and methicillin-resistant S. aureus (MRSA) ATCC BAA-1026 in a concentrationdependent manner (3). Furthermore, CG has been shown to exhibit antifungal activity. Methanol, butanol, hexane and aqueous leaf extracts of CG were tested against Trichophyton rubrum, Penicillium chrysogenum, Aspergillus niger, Candida albicans and Cryptococcus neoformans and reported that these extracts exhibited complete mycelial growth inhibition and spore germination at minimal 
concentration, whilst aqueous extract was ineffective against C. albicans, C. neoformans and P. chrysogenum (49). Also, the methanol leaf extract showed significant antifungal activity against A. niger, A. flavus, Rhizopus indicus and Mucor indicus when compared with the aqueous extract (14). CG root extract was active against Propionibacterium acnes and Staphylococcus epidermis with a minimum inhibitory concentration (MIC) of $0.675 \mathrm{mg} / \mathrm{mL}$ and $2 \mathrm{mg} / \mathrm{mL}$ respectively, indicating its antidermatophytic activity (50). In contrast, leaf extract was ineffective against dermatophytosis causing bacteria such as Trichophyton rubrum and Trichophyton mentagrophytes (51). Studies indicate that extraction methods play an important role in determining antimicrobial property. For instance, hot hydromethanolic extract of the bark resists the growth of fungi $C$. albicans with the zone of inhibition of $13 \mathrm{~mm}$ whereas cold hydromethanolic extract exhibited insensitivity to the fungus (41). Further, while investigating the principal compounds of the extracts of CG, tryptanthrin, indirubin and isatin have been proved to attribute to its antimicrobial property. Costa et al have been successful in identifying the presence of tryptanthrin in the dichloromethane fraction of ethanol flower extract of CG and its antibacterial activity against MRSA with a MIC of $156 \mu \mathrm{g} / \mathrm{mL}$ (52). Al-Dhabi et al subjected chloroform fruit extract to HPLC-DAD analysis and quantified indirubin to be $0.0918 \%$ whose antibacterial and antifungal activity is well documented (47). Furthermore, Tripathi and Sonawane were successful in isolating isatin from the floral parts of CG and synthesized a derivative compound, N, N'-(-2 Oxo-3'-H spiro[indoline 3,2'-[1,3,4]thiadiazole]3'5'-diyl)diacetamide (38). Studies prove that several such isatin derivatives were found to possess antimicrobial activity. Not many studies have been carried out concerning the antimycobacterial activity of CG. However, in a recent work, chloroform extract obtained from leaves of CG has been found to possess antimycobacterial activity against Mycobacterium smegmatis at a minimal inhibitory concentration of $64 \mu \mathrm{g} / \mathrm{mL}$ (53). On the contrary, chloroform fruit extract showed low antimycobacterial activity against $M$. tuberculosis $\mathrm{H}^{37} \mathrm{Rv}$ (HR-Sen) ATCC 27294 and M. tuberculosis XRD-1 strains (47). Recently, researchers focussed on the pharmacological study of nanoparticles obtained from plant extract. In one such study, silver nanoparticles obtained from flower extract demonstrated good effects against E. coli, B. subtilis and $P$. aeruginosa with a zone of inhibition of $15 \mathrm{~mm}$ (46).

\section{Anthelmintic activity}

Helminthic infection is one of the major problems for livestock all over the world. Development of antihelminthic resistance made the researchers overlook for plant-based product. In vitro studies revealed that CG leaves and flowers possess antihelminthic property (54). The extracts of leaves and flowers were tested against
Pheretima posthuma by worm motility assay. By observing the time of paralysis and time of death, it was reported that chloroform, ethanol and acetone extracts obtained from CG flowers and methanol extract obtained from CG leaves showed better antihelminthic effect at the concentration of $100 \mathrm{mg} / \mathrm{mL}$ (55).

\section{Anti-inflammatory activity}

Inflammation is a body's physiological response against intrinsic and/or extrinsic factors. In vitro and in vivo studies have implicated the role of CG in counteracting inflammation. In an in vitro study, the methanolic flower extract stabilizes the human red cell membrane at a dose of $500 \mu \mathrm{g} / \mathrm{mL}$ compared with the ethanolic flower extract and the standard drug, diclofenac. The flower extracts inhibited hypotonicity induced RBC membrane lysis. Since the RBC membrane is similar to the lysosomal membrane, the inhibition is taken as a measure of antiinflammatory activity (44). Different extracts from leaves were explored in an in vivo study for inflammatory pain (formalin-induced licking) and acute inflammation (carrageenan-induced peritonitis). The study showed that hexane, ethanol and ethyl acetate extracts inhibited leukocyte migration at higher doses (30 and $100 \mathrm{mg} / \mathrm{kg}$ ). The extracts were found to reduce cytokines such as tumor necrosis factor- $\alpha$, and inhibit interleukin- $1 b$ and nitric oxide production. The flower extract was also reported to reduce the paw licking during first and second phases (20). Similar anti-inflammatory study was carried out with flowers and bark of CG in the carrageenan-induced hind paw edema model and the observed mean paw volume was compared with the standard drug, indomethacin. Benzene, ethanol and aqueous extracts obtained from the flower and aqueous extracts obtained from bark showed a marked reduction in inflammation after 3 hours of administration (56).

\section{Neuropharmacological activity}

In a study exploring the neuropharmacological activity, Gupta et al analyzed the effect of methanolic extract of flower with respect to spontaneous motor activity, rota-rod performance and phenobarbital induced hypnosis in mice. The extract exhibited a significant reduction in spontaneous motor activity and the onset of phenobarbitone induced sleep, dose-dependently $(100,250$ and $500 \mathrm{mg} / \mathrm{kg})$. However, the extract had no effect in motor coordination as evident from the rota-rod performance (26). In addition, anti-depressant activity of CG has been confirmed in its roots and leaves. Methanol extract obtained from leaves were given orally to mice at a dosage of 125,250 , and $500 \mathrm{mg} / \mathrm{kg}$ body weight and the tail suspension test (TST), forced swim test (FST) and reserpine antagonism were carried out in the tested mice. The extract has been shown to reduce immobility time in TST and FST, and in reserpine antagonism, it significantly 
reduced the duration of catalepsy and ptosis. Furthermore, compound 3 isolated from petroleum ether extract of the leaf was found to implicate the same result with respect to TST and despair swim test but at lower concentration (1, $2.5,5 \mathrm{mg} / \mathrm{kg}$ ) suggesting its antidepressant activity (57). The use of anxiolytic drugs helps to induce relaxation and hypnosis (58). C. guianensis extracts were explored for its effect in controlling anxiety. Methanolic and aqueous flower extracts were found to have anxiolytic activity at a dose of $500 \mathrm{mg} / \mathrm{kg}$ as observed from the results of the elevated plus maze, light and dark, and open field test (26).

\section{Antihyperglycemic and antidiabetic activities}

Different parts of CG were tested to evaluate its antidiabetic activity. Morankar et al fed alloxan induced mice with the aqueous and methanolic extracts obtained from flowers at a dose of $100 \mathrm{mg} / \mathrm{kg}$ body weight. The extracts showed significant $(P<0.05)$ reduction in blood glucose level compared with the standard, metformin (59). One of the therapeutic approaches for diabetes is to control postprandial hyperglycemia which can be accomplished by inhibiting gastrointestinal carbohydrate hydrolyzing enzymes such as $\alpha$-amylase and $\alpha$-glucosidase (60). A study was carried out to find the effect of methanolic extract of leaves on the aforementioned carbohydrate hydrolyzing enzymes and found that the extract could control the enzymes dose-dependently highlighting inhibition of $\alpha$-amylase and $\alpha$-glucosidase with sucrose as substrate and $\alpha$-glucosidase with maltose as substrate at an $\mathrm{IC}_{50}$ value of $2.86 \mathrm{mg} / \mathrm{mL}, 2.38 \mathrm{mg} / \mathrm{mL}$ and 2.49 $\mathrm{mg} / \mathrm{mL}$, respectively. Leaves are rich in polyphenolic compounds including hydroxycinnamic acids, rosmarinic acid, caffeic acid and kaempferol-3-neohesperidoside, triterpenoid and $\beta$-amyrin palmitate. These compounds were reported to have inhibitory activity against carbohydrate hydrolyzing enzymes (61). Further, reactive oxygen species are considered to be the underlying cause for $\beta$ cell dysfunction, insulin resistance, impaired glucose tolerance and type 2 diabetes. Gold nanoparticles obtained from CG leaves have increased lipid peroxidation, and antioxidant enzymes such as superoxide dismutase, glutathione reductase and catalase enzyme activities in diabetic rats and thus alleviating hyperglycemia condition by regulating oxidative stress (48). There is a close association between obesity and type 2 diabetes. Type 2 diabetes is characterized by insulin insensitivity. Obesity along with insulin resistance and hyperlipidemia are related to macrovascular diabetic complications (62). CG has been explored for its anti-obesity potential and a positive result was obtained. The methanolic extract $(100,200 \mathrm{mg} / \mathrm{kg}$ body weight) of the plant reduced total serum cholesterol, low-density lipoproteins, triglycerides, very low-density lipoproteins and increased the highdensity lipoproteins in obese rats when compared with the standard, Atorvastatin. Further, the extract has demonstrated significant inhibition of atherosclerotic plaque formation (63).

\section{Anticytotoxic activity}

Extracts of leaves, fruits and flowers were reported to exhibit anticancer, antiproliferative, cytotoxic and antitumor activities. Additionally, compounds particularly tryptanthrin and isatin isolated from CG have exhibited different extent of antagonizing the development and proliferation of cancer cells. Studies elucidating the anticancer potential of CG were carried out in various cell lines but the mechanisms underlying the anticancer potential have not so far been reported.

Microculture tetrazolium test (MTT) assay was carried out to determine the cytotoxic ability of ethyl acetate leaf extract (ELE) and crude methanolic flower extract (CMF) on HT-29 cell line. ELE and CMF had better cytotoxicity with $\mathrm{IC}_{50}$ values of 300.0 and $220.0 \mu \mathrm{g} / \mathrm{mL}$, respectively (43). On the other hand, MTT assay was performed using ethanol extract of fruit rind in HEP G2, Vero cell line, breast cancer cell line and HT 29-colon cancer cell line and obtained an $\mathrm{IC}_{50}$ value of $62.5 \mu \mathrm{g} / \mathrm{mL}$ for all the cell lines except breast cancer cell line for which the extract exhibited an $\mathrm{IC}_{50}$ value of $15.625 \mu \mathrm{g} / \mathrm{mL}$. The study denoted that cytotoxicity was dose-dependent (34). Similar MTT assay was accomplished with the methanolic flower extract on HeLa, NIH 3T3 and HepG2 cancer cell lines. The extract showed significant cytotoxic activity with $\mathrm{IC}_{50}$ values of 202.6, 280 and $470.8 \mu \mathrm{g} / \mathrm{mL}$ for HeLa, NIH 3T3 and HepG2 cancer cell lines, respectively. Further, the methanolic extract was reported to contain quercetin and stigmasterol which are well known for their anticancer efficacy $(64,65)$.

Nanoparticles obtained from plant extracts have demonstrated a significant role in counteracting cancer cells. Their cytotoxicity is due to surface morphology and size. Varied attempts were made with different types of nanoparticles obtained from the extracts of various parts of CG to study the anticancer potential. In one such attempt, iron oxide nanoparticles $\left(\mathrm{CGFeO}_{4} \mathrm{NP}\right)$ were synthesized using CG fruit extract (CGFE) and its cytotoxicity was compared with CGFE by performing MTT assay on human hepatocellular carcinoma cells (HepG2). Both the extracts CGFE and nanoparticles $\left(\mathrm{CGFeO}_{4} \mathrm{NP}\right)$ exhibited its cytotoxicity in a dose-dependent manner with $\mathrm{IC}_{50}$ values of 120 and $44.51 \mu \mathrm{g} / \mathrm{mL}$, respectively. Further, CGFE and $\mathrm{CGFe}_{3} \mathrm{O}_{4} \mathrm{NPs}$ treated HepG2 cells showed modified features like condensed nuclei, apoptotic bodies of nuclear morphology and membrane blebbing. These results made the authors to strongly suggest that $\mathrm{CGFe}_{3} \mathrm{O}_{4} \mathrm{NPs}$ induces HepG2 cell death through caspase-cascade mediated mitochondrial dysfunction and apoptosis (66). A similar MTT assay was carried out by the same author with palladium nanoparticles (CGPdNPs) obtained from CG fruit extract (CGFE) on lung cancer cell line A549. 
Comparatively, CGPdNP appeared to exhibit significant anticancer activity than CGFE with an $\mathrm{IC}_{50}$ value of 121 $\mu \mathrm{g} / \mathrm{mL}$. Cells exposed to CGPdNPs showed changes in morphological and cytological changes (67). On the other hand, in another study gold nanoparticles were synthesized using flower extract of CG and its effect on proliferation of human promyelocytic leukemia (HL-60) cell was determined by MTT assay. The nanoparticles treated cells exhibited changes including DNA fragmentation and damage leading to apoptosis (68).

Furthermore, isatin isolated from the flowers exhibited cytotoxicity against HL-60 cells dose-dependently with an $\mathrm{IC}_{50}$ of $2.94 \mu \mathrm{g} / \mathrm{mL}$. Isatin-treated cells induced DNA fragmentation and apoptosis of HL-60 cells (69).

\section{Wound healing activity}

Studies justify the use of CG in wound healing in folklore medicine. In one such study, the ethanol extract of the whole plant was evaluated for its potential to heal the wound in rats by carrying out two methods: excision and incision models. Parameters such as wound contraction, epithelisation, tensile strength and hydroxyproline content were then determined and it was reported that there was a decrease in the surface area of the wound and increase in the tensile strength and hydroxyproline concentration. Furthermore, complete epithelisation was observed within 15 days (70). In another study, hydroethanolic leaf extract containing flavonoids such as $2^{\prime}, 4^{\prime}$-dihydroxy6'-methoxy-3',5'-dimethylchalcone and 7-hydroxy-5methoxy-6,8-dimethyl flavanone and the phenolic acid 4-hydroxybenzoic acid was reported to stimulate human skin fibroblast proliferation and promote UV absorption (27). Fibroblast plays an incredible role in wound healing by enhancing wound contraction (71).

\section{Insecticidal/larvicidal activity}

Plant-based insecticide provides an alternative to synthetic insecticide. Hence, a number of investigations has been performed to assess the plant-insect interactions to unveil their insecticidal potency. Leaves of CG were proclaimed to exhibit insecticidal activity. The aqueous extract obtained from leaf decreases the survival rate of Bemisia tabaci nymphs and adults by $29.2 \%$ and $35.34 \%$, respectively. The eggs exhibited low sensitivity towards the extract with the reduction in survival rate by $19.2 \%$. Moreover, the extract showed high repellency effect towards B. tabaci adults. Further, they suggested that the high repellency effect might be due to the aromatic property of CG (72).

Larvicidal property of leaf, flowers and fruits of CG were well documented. The chloroform and petroleum ether extracts of flower and chloroform extract of fruit displayed significant larvicidal activity against third or early fourth instar larvae of Culex quinquefasciatus (73). Likewise, hexane, chloroform and ethyl acetate extracts of leaf were more potent against Spodoptera litura and Helicoverpa armigera with hexane extract exhibiting maximum larvicidal activity by $68.66 \%$ and pupicidal activity by $100 \%$ against $S$. litura and maximum ovicidal activity by $64.28 \%$ against $H$. armigera with $\mathrm{LC}_{50}$ value of $2.62 \%(74,75)$. Further, the ethyl acetate extract of leaves was found to control Musca domestica, housefly larva with $\mathrm{LC}_{50}$ and $\mathrm{LC}_{90}$ of 479.137 and $1969.851 \mathrm{ppm}$ (76). In addition, nanoparticles synthesized from CG were evaluated for its insecticidal/larvicidal activity. Subramaniam et al. synthesized gold nanoparticles from flower extract and demonstrated its toxicity against Anopheles stephensi at larval, pupal and adult stages (77). Likewise, silver nanoparticles synthesized from leaf and fruit exhibited larvicidal activity against Aedes aegypti. These silver nanoparticles showed dose-dependent larvicidal activity (7).

\section{Hepatoprotective activity}

Demonstration of the hepatoprotective role of CG leaf extract was carried out against $\mathrm{CCl}_{4}$ induced liver damage in Wistar Albino rats of either sex. Assessment of liver marker enzymes at doses of $150 \mathrm{mg} / \mathrm{kg}$ body weight and 300 $\mathrm{mg} / \mathrm{kg}$ body weight revealed significant hepatoprotective activity (25). In another study, the methanol extract of CG leaves was observed to show significant activities on reduced glutathione, catalase, superoxide dismutase, glutathione reductase, malondialdehyde and glutathione peroxidase levels in $\mathrm{CCl}_{4}$-olive oil induced damaged liver. In addition, histological studies on liver tissues substantiated the biochemical results (78).

\section{Antinociceptive activity}

Pain is the sign of injury and illness and medical community mostly depend on the analgesic drug, morphine to deal with it. Plants with antinociceptive property pave a way for the discovery of new antianalgesic drugs. CG leaves extract was evaluated for its antinociceptive activity through three analgesic models including acetic acid-induced contortions, tail flick, and hot plate. It has been found that the crude ethanol extract and its fraction exhibited significant activity in acetic acid-induced contortions and hot plate method while the highest effect was observed with hexane and ethyl acetate fractions in the tail flick model. The antinociceptive activity is partly mediated by nitric oxide pathways and opioid and cholinergic systems (20).

\section{Anti-ulcer activity}

The antiulcer activity of methanol extract of flowers in Wistar rats revealed that at doses of $400 \mathrm{mg} / \mathrm{kg} \mathrm{b.w}$, the ulcer protection level and ulcer index score were found to be $86.82 \%$ and $4.93 \pm 0.22 \%$, respectively. Furthermore, the extract reduced gastric juice, free acidity $(61.83 \pm 4.71)$, total acidity $(88.50 \pm 5.09)$ and pepsin $(15.36 \mu \mathrm{g} / \mathrm{mL})$ 
when compared with ulcer induced control group (79). It was suggested that the protective action of the CG flowers might be due to the richness in phytochemicals such as tannins and flavonoids. Another study performed using the ethanolic extract of CG leaves in experimental rats indicated that at doses of 150 and $300 \mathrm{mg} / \mathrm{kg}$ body weight there was a significant decrease in ulcer index, gastric volume and free acidity compared to control. The extract has recorded significant inhibition of the gastric lesions induced by pylorus ligation induced ulcer and ethanolinduced gastric ulcer. It has been claimed that the antiulcer property is attributed to the anti-secretory activity of the extract (80).

\section{Immunomodulatory activity}

Both in vitro and in vivo studies have claimed CG to modulate (suppress or stimulate) the components of the immune system. Methanol extract of CG leaves was tested for hypersensitivity reactions using sheep red blood cell as the antigen in both the studies. It has been found to increase phagocytosis. It enhances the phagocytic functions of neutrophils and also it stimulates a cellmediated and humoral mediated immune response (81).

\section{Other activities}

In addition to the aforementioned pharmacological activities, other biological activities of extracts from CG including antiurolithic, antiarthritic, antifertility and antidiarrheal, have also been evaluated.

Urolithiasis is one of the most common diseases and is characterized by the formation of all types of urinary calculi in the urogenital tract. Commonly, urinary stones are composed of calcium phosphate or calcium oxalate. Less common stones include uric acid, struvite or cystine stones. Assessing an in vitro study has shown that aqueous extract obtained from CG leaves has the ability to dissolve $40.8 \pm 0.032 \%$ calcium oxalate (82). In a similar study, the methanolic extract obtained from CG leaves has inhibited the growth of struvite crystals estimated by the decrease in the weight of the crystals from $2.53 \mathrm{~g}$ to $0.18 \mathrm{~g}$ (83). Furthermore, an investigation pertaining to anti-coagulant activity reported that aqueous and chloroform extract obtained from CG leaves were known to show better anticoagulant activity by increasing the prothrombin time when compared with EDTA (17). Likewise, CG leaves inhibited ADP induced human platelet aggregation in a dose-dependent manner, thus preventing the risk of development and progression of atherosclerosis (84).

Antifertility drugs are mostly synthetic hormones. These drugs are made up of progesterone derivatives or a combination of progesterone and estrogen derivatives. Plant-based anti-fertility drugs can be an alternative. Various solvent extracts obtained from CG bark and flowers were tested for anti-fertility activity in adult female rats. Both flower and bark were reported to influence estrous cycle and reduce the number of implantations in pregnant rats by interfering in the receptive stage of the uterus and endometrial sensitivity for decidualization (85).

Antidiarrheal activity of CG leaves was undertaken on castor oil induced diarrhea in albino rats with aqueous and methanolic extracts at a concentration of $100 \mathrm{mg} / \mathrm{kg}$ body weight. The report revealed that diarrhoeal episodes have been reduced significantly compared to the standard drug, loperamide (86).

Hyperuricemia is a condition that predisposes to gout and gouty arthritis. The key enzyme that plays an important role in uric acid production is xanthine oxidase. CG fruit extract has been reported to inhibit xanthine oxidase and the percentage of inhibition was found to be concentration dependent showing maximum inhibition of $79.97 \%$ at $400 \mu \mathrm{g} / \mathrm{mL}$ compared to standard, allopurinol (87).

\section{Toxicology of Couroupita guianensis}

Few studies assessed the toxicological aspects of CG. Acute toxicity tests of CG methanolic flower extract and ethanolic leaf extract have been evaluated in the Albino mice. There was no sign of mortality and behavioral changes in the mice when administered orally up to a maximum of $2 \mathrm{~g} / \mathrm{kg}$ and $3 \mathrm{~g} / \mathrm{kg}$ with methanolic flower extract and ethanolic leaf extract, respectively $(25,26)$. Studies revealed that higher doses may be recommended, however, more research has to be carried out to fix the dosage.

\section{Conclusion}

In this review, the results of work pertaining to CG are highlighted comprehensively, which will provide assistance for further research to be undertaken in the future. Biological activities discussed in this paper validate almost all the traditional usage of CG. Reports on phytochemical composition demonstrate that CG has many bioactive components, notably isatin, indirubin and tryptanthrin. Further researches, specifically on mechanism of action, isolation and purification of active compounds and pharmacokinetics are necessary to evaluate its obtained biological activity. In addition, toxicological evaluation and more in vivo studies have to be carried out to establish its efficiency and safety that would warrant as a source of drug in the near future.

\section{Authors' contributions}

VA contributed in designing the study, and supervising and editing the manuscript. LAS performed data collection and manuscript preparation. Final version of the manuscript was confirmed by both authors. All authors contributed equally.

\section{Conflict of interests}

None. 


\section{Ethical considerations}

Not applicable.

\section{Funding/Support}

There is no financial support for this work.

\section{References}

1. Jamshidi-Kia F, Lorigooini Z, Amini-Khoei H. Medicinal plants: past history and future perspective. J Herbmed Pharmacol. 2018;7(1):1-7. doi: 10.15171/jhp.2018.01.

2. Akerele O. Summary of WHO guidelines for the assessment of herbal medicines. Herbal Gram. 1993;28(13):13-9.

3. Majumder S, Elango EM, Hoebe CJ, Rahmatullah M. Antibacterial studies with methanol extract of Couroupita guianensis flowers against methicillin-resistant Staphylococcus aureus. World J Pharm Pharm Sci. 2014;3(9):543-50.

4. Shekhawat MS, Manokari M. Impact of auxins on vegetative propagation through stem cuttings of Couroupita guianensis Aubl.: a conservation approach. Scientifica (Cairo). 2016;2016:6587571. doi: 10.1155/2016/6587571.

5. USDA. Agricultural Research Service, National Plant Germplasm System [Internet]. Germplasm Resources Information Network (GRIN-Taxonomy). National Germplasm Resources Laboratory, Beltsville, Maryland; 2018. Available from: https://npgsweb.ars-grin.gov/gringlobal/ taxonomydetail.aspx?id=11869. Accessed August 26, 2018.

6. Reshma Y, Sunilkumar T. Phytochemical analysis of fruit pulp of Couroupita guianensis Aubl. J Pharmacogn Phytochem. 2018;7(2):877-9.

7. Vimala RT, Sathishkumar G, Sivaramakrishnan S. Optimization of reaction conditions to fabricate nano-silver using Couroupita guianensis Aubl. (leaf \& fruit) and its enhanced larvicidal effect. Spectrochim Acta A Mol Biomol Spectrosc. 2015;135:110-5. doi: 10.1016/j.saa.2014.06.009.

8. Shete SA, Shah GN, Walke SS, Patil VS, Patil KD, Killedar SG. Standardization and antibacterial activity of Couroupita guianensis fruit shell extract. Int J Biol. 2013;2(1):360-4.

9. Pratap GP, Prasad GP, Sudarsanam G. Ethno medical studies in Kailasagirikona forest range of Chittoor district, Andhra Pradesh. Anc Sci Life. 2009;29(2):40-5.

10. Ganesh P, Sudarsanam G. Ethnomedicinal plants used by Yanadi tribes in Seshachalam biosphere reserve forest of Chittoor district, Andhra Pradesh India. Int J Pharm Life Sci. 2013;4(11):3073-9.

11. Begum R, Rahman MS, Chowdhury AMS, Hasan CM, Rashid MA. Secondary metabolites (Triterpenes) from Couroupita guianensis. Orient Pharm Exp Med. 2009;9(2):200-5. doi: 10.3742/OPEM.2009.9.2.200.

12. Kekuda TRP. Antimicrobial, radical scavenging, and insecticidal activity of leaf and flower extracts of Couroupita guianensis Aubl. Int J Green Pharm. 2017;11(03): 171-9.

13. Khan MS, Kato-Noguchi H. Assessment of allelopathic potential of 'Couroupita guianensis' Aubl. Plant Omics. 2016;9(2):115-20.

14. Kavitha R, Kamalakannan P, Deepa T, Elamathi R, Sridhar S, Suresh Kumar J. In vitro antimicrobial activity and phytochemical analysis of Indian medicinal plant Couroupita guianensis Aubl. J Chem Pharm Res. 2011;3(6):115-21.
15. Dahlgren BE, Lang H. The cannon-ball tree: the monkeypots. Chicago: Field Museum of Natural History; 1924.

16. Nelson EK, Wheeler DH. Some Constituents of the Cannonball Fruit (Couroupita guianensis, Aubl.). J Am Chem Soc. 1937;59(12):2499-500. doi: 10.1021/ ja01291a005.

17. Uppala PK, Murali Krishna B, Atchuta Kumar K, Vinay Ramji DJ. Evaluation of anti-coagulant activity of the chloroform and aqueous extracts of the leaves of Couroupita guianensis. Int J Pharm Pharm Res. 2016;6(4):189-99.

18. The Integrated Taxonomic Information System on-line database. Available from: http://www.itis.gov. Accessed May, 30, 2019.

19. Lim TK. Edible medicinal and non-medicinal plants. Dordrecht, The Netherlands: Springer; 2012. doi: 10.1007/978-94-007-2534-8_14.

20. Pinheiro MM, Fernandes SB, Fingolo CE, Boylan F, Fernandes PD. Anti-inflammatory activity of ethanol extract and fractions from Couroupita guianensis Aublet leaves. J Ethnopharmacol. 2013;146(1):324-30. doi: $10.1016 /$ j.jep.2012.12.053.

21. Kumar CS, Naresh G, Sudheer V, Veldi N, Elumalai A. A short review on therapeutic uses of Couroupita guianensis Aubl. Int Res J Pharm Appl Sci. 2011;1(1):105-8.

22. Dave GR, Patel RM, Patel RJ. Characteristics and composition of seeds and oil of Couroupita guianensis Aubl. from Gujarat, India. Fette, Seifen, Anstrichmittel. 1985;87(3):111-2. doi: 10.1002/lipi.19850870307.

23. Prabhu V, Ravi S. Isolation of phytoconstituents from the flowers of Couroupita guianensis. Indian J Chem. 2017;56:709-13.

24. Ramalakshmi C, Ranjitsingh AJ, Kalirajan K, Kalirajan A, Athinarayanan G, Mariselvam R. A preliminary screening of the medicinal plant Couroupita guianensis for its antimicrobial potential against clinical and fish-borne pathogens. Elixir Appl Biol. 2013;57:14055-7.

25. Elumalai A, Bargavi K, Krishna S, Chinnaeswaraiah M. Evaluation of anti-oxidant and hepatoprotective activity of Couroupita guianensis leaves. J Cell Tissue Res. 2013;13(2):3745-8.

26. Gupta VH, Gunjal MA, Wankhede SS, Deshmukh VS, Juvekar AR. Neuropharmacological evaluation of the methanolic extract of Couroupita guianensis Aubl. flower in mice. Int J Pharm Phytopharmacol Res. 2012;1(5):242-6.

27. Martínez A, Conde E, Moure A, Domínguez H, Estévez RJ. Protective effect against oxygen reactive species and skin fibroblast stimulation of Couroupita guianensis leaf extracts. Nat Prod Res. 2012;26(4):314-22. doi: $10.1080 / 14786411003752094$.

28. Khan MR, Kihara M, Omoloso AD. Antibiotic activity of Couroupita guianensis. J Herbs Spices Med Plants. 2003;10(3):95-108. doi: 10.1300/J044v10n03_10.

29. Manokari M, Shekhawat MS. Biogenesis of zinc oxide nanoparticles using Couroupita guianensis Aubl. extractsA green approach. World Sci News. 2016;29:135-45.

30. Sen AK, Mahato SB, Dutta NL. Couroupitine A, a new alkaloid from Couroupita guianensis. Tetrahedron Lett. 1974;7:609-10.

31. Bergman J, Egestad B, Lindström JO. The structure of some indolic constituents in Couroupita guianensis Aubl. Tetrahedron Lett. 1977;18:2625-6. doi: 10.1016/S0040- 
4039(01)83838-7.

32. Rastogi RP, Mehrotra BN. Compendium of Indian medicinal plants: A CDRI series. 1979; 2.

33. Rastogi RP, Mehrotra BN. Compendium of Indian medicinal plants. Drug Research Preparative: A CDRI series. 1995;2:453.

34. Regina V, Uma Rajan KM. Phytochemical analysis, antioxidant and antimicrobial studies of fruit rind of Couroupita guianensis (Aubl). Int J Curr Sci. 2012;221:2627.

35. Gupta SK, Ghosal M, Choudhury D, Mandal P. Assessment of antioxidant activity and polyphenolic content of Couroupita guianensis during flower and fruit maturation. Int J Recent Sci Res. 2014;5(5):940-7.

36. Wong KC, Tie DY. Volatile constituents of Couroupita guianensis Aubl. flowers. J Essent Oil Res. 1995;7(2):225-7. doi: 10.1080/10412905.1995.9698507.

37. Khan AM, Shivashankara KS, Roy TK. Determining composition of volatiles in Couroupita guianensis Aubl. through headspace-solid phase micro-extraction (HSSPME). J Hortic Sci. 2014;9(2):161-5.

38. Tripathi RR, Sonawane RP. An extraction of the Isatin from the Couroupita guianensis (cannon ball tree) and a novel synthesis of the $\mathrm{N}, \mathrm{N}^{\prime}$-(2-oxo-3'H-spiro [indoline-3, 2'-[1, $3,4]$ thiadiazole]-3', 5'-diyl] diacetamide from the Isatin. Int Lett Chem Phys Astron. 2013;10:119-25.

39. Prabhu V, Ravi S, Elamaran S, Murugan K. Isolation and characterisation of phytoconstituents using low polar solvents from the flowers of Couroupita guianensis. Coimbatore, India: ICSSCCET; 2015.

40. Eknat AA, Shivchandraji LK. Beta amyrin palmitate Isolation from Couroupita guianensis Aubl. leaves. Indian Drugs. 2002;39(4):213-6.

41. Shivashankar M, Rajeshwari S, Nagananda GS, Rajath S, Chandan N. Comparative antioxidant and antimicrobial studies of cold and hot bark hydromethanolic extract of Couroupita guianensis Aubl. Res Pharm. 2013;3(6):6-13.

42. Anjaneyulu ASR, Rao SS. A new ketosteroid from the bark of Couroupita guianensis Aubl. Indian J Chem. 1998;37(4):382-6.

43. Sirisha M, Jaishree V. Phytochemical screening, antioxidant and antiproliferative activities of successive extracts of Couroupita guianensis Aubl. plant. Indian J Nat Prod Resour. 2018;9(1):22-7.

44. Sumathi $S$, Anuradha R. In vitro anti-inflammatory activity of flower extract of Couroupita guianensis Aubl. Int J Herb Med. 2016;4(5):5-8.

45. Kaneria M, Rakholiya K, Jakasania R, Dave R, Chanda S. Metabolite profiling and antioxidant potency of Couroupita guianensis Aubl. using LC-QTOF-MS based metabolomics. Res J Phytochem. 2017;11(3):150-69. doi: 10.3923/ rjphyto.2017.150.169.

46. Pandurangan P, Sahadeven M, Sunkar S, Dhana SK. Comparative analysis of biochemical compounds of leaf, flower and fruit of Couroupita guianensis and synthesis of silver nanoparticles. Pharmacogn J. 2018;10(2):315-23. doi: 10.5530/pj.2018.2.55.

47. Al-Dhabi NA, Balachandran C, Raj MK, Duraipandiyan V, Muthukumar C, Ignacimuthu S, et al. Antimicrobial, antimycobacterial and antibiofilm properties of Couroupita guianensis Aubl. fruit extract. BMC Complement Altern Med. 2012;12:242. doi: 10.1186/1472-6882-12-242.

48. Manimegalai S, Sridharan TB, Rameshpathy M, Devi Rajeswari V. Antioxidant, phytochemical screening and antimicrobial activity of Couroupita guianensis flower extract. Pharm Lett. 2014;6(6):251-6.

49. Keerthana V, Devakumar J, Sudha S. Inhibition of fungal mycelial growth and spore germination by Couroupita guianensis leaf extracts and its preliminary phytochemical analysis. Indian J Appl Microbiol. 2017;20(1):21-30.

50. Kumar GS, Jayaveera KN, Ashok Kumar CK, Vrushabendra Swamy BM, Sanjay Umachigi P, Kishore Kumar DV. Antibacterial screening of selected Indian medicinal plants against acne inducing bacteria. Pharmacologyonline. 2007;2:34-47.

51. Devi TS, Padmaja IJ, Sastry YN, Nagamani A. A study on anti dermatophytic potential of selected ethno medicinal plants against Trichophyton rubrum, a common etiologic agent in and around Visakhapatnam region (India). Asian Pac J Trop Biomed. 2012;2(3 Suppl):S1874-S8. doi: 10.1016/ S2221-1691(12)60512-7.

52. Costa DCM, Azevedo MMB, Silva DOE, Romanos MTV, Souto-Padron T, Alviano CS, et al. In vitro anti-MRSA activity of Couroupita guianensis extract and its component Tryptanthrin. Nat Prod Res. 2017;31(17):2077-80. doi: 10.1080/14786419.2016.1272110.

53. Nivedita P, Aranganathan V. Screening and identification of anti-mycobacterial plants. Int J Life Sci Pharma Res. 2019;9(1):66-73.

54. Rajamanickam V, Rajasekaran A, Darlin Quine S, Jesupillai M, Sabitha R. Anthelmintic activity of the flower extract of Couroupita guianensis. The Internet Journal of Alternative Medicine. 2008;8(1):1-3.

55. Elumalai A, Eswaraiah MC, Naresh K, Kumar R, Meruva A, Vidhyulatha C. In-vitro anthelmintic activity of Couroupita guianensis leaves in Indian adult earthworm. Int J Preclin Pharmaceut Res. 2013;3(1):47-9.

56. Geetha M, Saluja AK, Shankar MB, Mehta RS. Analgesic and anti-inflammatory activity of Couroupita guianensis Aubl. Journal of Natural Remedies. 2004;4(1):52-5.

57. Kulkarni M, Wakade A, Ambaye R, Juvekar A. Phytochemical and pharmacological studies of the leaves of Couroupita guianensis Aubl. Pharmacologyonline. 2011;3:809-14.

58. Latha K, Rammohan B, Sunanda BP, Maheswari MS, Mohan SK. Evaluation of anxiolytic activity of aqueous extract of Coriandrum sativum Linn. in mice: a preliminary experimental study. Pharmacognosy Res. 2015;7(Suppl 1):S47-51. doi: 10.4103/0974-8490.157996.

59. Morankar PG, Dhake AS, Kumbhare MR, Ushir YV, Surana AR, Patil SD. An evaluation of the antidiabetic effects of Couroupita guianensis Aubl. flowers in experimental animals. Indo Am J Pharm Res. 2013;3(4):3114-22.

60. Kim YM, Jeong YK, Wang MH, Lee WY, Rhee HI. Inhibitory effect of pine extract on alpha-glucosidase activity and postprandial hyperglycemia. Nutrition. 2005;21(6):756-61. doi: 10.1016/j.nut.2004.10.014.

61. Somani G, Chaudhari R, Sancheti J, Sathaye S. Inhibition of carbohydrate hydrolysing enzymes by methanolic extract of Couroupita guianensis leaves. Int J Pharm Bio Sci. 
2012;3(4):511-20.

62. Al-Goblan AS, Al-Alfi MA, Khan MZ. Mechanism linking diabetes mellitus and obesity. Diabetes Metab Syndr Obes. 2014;7:587-91. doi: 10.2147/dmso.s67400.

63. Ramyasai M, Babu SM, Vadivel K. Anti-obesity and atheroscelerotic activity of methanolic extract of Couroupita guianensis Aubl. flowers in rats fed with high fat diets. Int J Univ Pharm Bio Sci. 2013;2(6):288-300.

64. Rauf A, Imran M, Khan IA, Ur-Rehman M, Gilani SA, Mehmood Z, et al. Anticancer potential of quercetin: A comprehensive review. Phytother Res. 2018;32(11):210930. doi: 10.1002/ptr.6155.

65. Woyengo TA, Ramprasath VR, Jones PJ. Anticancer effects of phytosterols. Eur J Clin Nutr. 2009;63(7):813-20. doi: 10.1038/ejcn.2009.29.

66. Sathishkumar G, Logeshwaran V, Sarathbabu S, Jha PK, Jeyaraj M, Rajkuberan C, et al. Green synthesis of magnetic Fe3O4 nanoparticles using Couroupita guianensis Aubl. fruit extract for their antibacterial and cytotoxicity activities. Artif Cells Nanomed Biotechnol. 2018;46(3):58998. doi: 10.1080/21691401.2017.1332635.

67. Gnanasekar S, Murugaraj J, Dhivyabharathi B, Krishnamoorthy V, Jha PK, Seetharaman P, et al. Antibacterial and cytotoxicity effects of biogenic palladium nanoparticles synthesized using fruit extract of Couroupita guianensis Aubl. J Appl Biomed. 2018;16(1):59-65. doi: 10.1016/j.jab.2017.10.001.

68. Geetha R, Ashokkumar T, Tamilselvan S, Govindaraju K, Sadiq M, Singaravelu G. Green synthesis of gold nanoparticles and their anticancer activity. Cancer Nanotechnol. 2013;4(4-5):91-8. doi: 10.1007/s12645-0130040-9.

69. Premanathan M, Radhakrishnan S, Kulangiappar K, Singaravelu G, Thirumalaiarasu V, Sivakumar T, et al. Antioxidant \& anticancer activities of isatin (1H-indole-2,3dione), isolated from the flowers of Couroupita guianensis Aubl. Indian J Med Res. 2012;136(5):822-6.

70. Umachigi SP, Jayaveera KN, Ashok Kumar CK, Kumar GS. Antimicrobial, wound healing and antioxidant potential of Couroupita guianensis in rats. Pharmacologyonline. 2007;3:269-81.

71. Li B, Wang JH. Fibroblasts and myofibroblasts in wound healing: force generation and measurement. J Tissue Viability. 2011;20(4):108-20. doi: 10.1016/j.jtv.2009.11.004.

72. Anu Y, Mendhulkar VD. Repellency and toxicity of Couroupita guianensis leaf extract against Silverleaf Whitefly (Bemisia tabaci). International Journal of Scientific and Research Publications. 2015;5(4):1-4.

73. Desal S, Golatkar SG, Rane JB, Ambaye RY, Kamath VR. Larvicidal property of Couroupita guianensis Aubl. Indian Drugs. 2003;40(8):484-6.

74. Baskar K, Ignacimuthu S, Jayakumar M. Toxic Effects of Couroupita guianensis Against Spodoptera litura (Fabricius) (Lepidoptera: Noctuidae). Neotrop Entomol. 2015;44(1):84-91. doi: 10.1007/s13744-014-0260-7.
75. Baskar K, Ignacimuthu S. Ovicidal activity of Couroupita guianensis (Aubl.) against cotton bollworm Helicoverpa armigera (Hübner) (Lepidoptera: Noctuidae). Arch Phytopathology Plant Protect. 2013;46(13):1571-9. doi: 10.1080/03235408.2013.771862.

76. Suresh M, Premraj L, Kalaiarasi JM. Bioefficacy and larvicidal activity of Couroupita guianensis (Aubl) against housefly, Musca domestica (L). J Entomol Zool Stud. 2017;5(5):429-33.

77. Subramaniam J, Murugan K, Panneerselvam C, Kovendan K, Madhiyazhagan P, Dinesh D, et al. Multipurpose effectiveness of Couroupita guianensis-synthesized gold nanoparticles: high antiplasmodial potential, field efficacy against malaria vectors and synergy with Aplocheilus lineatus predators. Environ Sci Pollut Res Int. 2016;23(8):7543-58. doi: 10.1007/s11356-015-6007-0.

78. Sundarajan R, Koduru R. Hepatoprotective and antioxidant effects of Couroupita guianensis on carbon tetrachloride-induced liver damage. International Journal of Phytomedicine. 2015;7(3):281-9.

79. Ramalakshmi C, Kalirajan A, Ranjitsingh AJA, Kalirajan K. Bioprospecting of medicinal plant Couroupita guianensis for its potential anti-ulcer activity. Int J Appl Biol Pharm Technol. 2014;5(3):226-32.

80. Elumalai A, Naresh V, Eswaraiah MC, Narendar P, Kumar R. Evaluation of antiulcer activity of Couroupita guianensis Aubl leaves. Asian J Pharm Technol. 2012;2(2):64-6.

81. Pradhan D, Panda PK, Tripathy G. Evaluation of the immunomodulatory activity of the methanolic extract of Couroupita guianensis Aubl. flowers in rats. Nat Prod Radiance. 2009;8(1):37-42.

82. Desai SD, Panchal HN, Soni MK, Mishra P, Meshram DB. In-vitro antiurolithiatic and antioxidant activity of Couroupita guianensis Aubl leaves. Der Pharmacia Sinica. 2018;9(1):1-6.

83. Manjula K, Perciyal P, Priscella S. Growth characterization of struvite crystals influenced by Couroupita guianensis extract. World J Pharm Pharm Sci. 2018;7(3):1130-40. doi: 10.20959/wjpps20183-11176.

84. Elumalai A, Eswaraiah MC, Didala A. Investigations on anti-oxidant, anti-arthritic and antiplatelet studies in Couroupita guianensis Aubl leaves by in vitro methods. Pharma Sci Monit. 2012;3(3):2262-9.

85. Geetha M, Shankar MB, Mehta RS, Saluja AK. Antifertility activity of Artabotrys odoratissimus Roxb. and Couroupita guianensis Aubl. Journal of Natural Remedies. 2005;5(2):121-5.

86. Elumalai A, Eswaraiah MC, Koppula Naresh K, Kumar R, Meruva A, Vidhyulatha C. Antidiarrhoeal activity of Couroupita guianensis leaves on castor oil induced diarrhoea in albino rats. Int J Pharmacol Res. 2013;3(2):42-4.

87. Syed Ali M, Anuradha V, Keerthiga R, Yogananth N, Sheeba H. Effect of Couroupita guianensis on xanthine oxidase activity and its potent role in treatment of Gout. Asian J Pharm Pharmacol. 2017;3(6):215-9. 